Claus Holm \& Finn Schøler

Reduction of Asymmetric Information through Corporate Governance Mechanisms - The Importance of Ownership Dispersion and International Orientation

Accounting

Research Group 


\title{
Reduction of Asymmetric Information through Corporate Governance Mechanisms - The Importance of Ownership Dispersion and International Orientation
}

\author{
By
}

Claus Holm, Professor, Ph.D.,

Department of Business Studies, Aarhus School of Business, University of Aarhus.

hoc@asb.dk

\author{
Finn Schøler, \\ Associate Professor, Ph.D., \\ Department of Business Studies,
} Aarhus School of Business, University of Aarhus.

fsc@asb.dk 


\title{
Reduction of Asymmetric Information through Corporate Governance Mechanisms - The Importance of Ownership Dispersion and International Orientation
}

\begin{abstract}
Manuscript Type: Empirical

Research Question/Issue: Is the reduction of asymmetric information through Corporate Governance mechanisms more important for some listed companies than for others? The purpose of this study is to examine how differences in "ownership dispersion" and "international orientation" affect the particular use of the Corporate Governance mechanisms "transparency" and "board independence" in listed companies.

Research Findings/Insights: Our findings are based on a Danish dataset which includes 100 listed companies. We find that transparency is a more important Corporate Governance mechanism for companies with an international orientation, while differences in ownership dispersion do not affect the use of this mechanism. In contrast, we find that board independence is a more important Corporate Governance mechanism for companies with dispersed ownership while international orientation has less importance.
\end{abstract}

Theoretical/Academic Implications: The study contributes to an improved understanding of the circumstantial relationship between good Corporate Governance and 
good corporate performance. This is important in order to interpret differences in prior research findings and provide insight for the design of future studies of the seemingly endogenous nature of many Corporate Governance relationships.

Practitioner/Policy Implications: The requirement to adhere to the "comply or explain rules" for Corporate Governance has become commonplace for listed companies. The study provides insight into valid reasons for differences in compliance. Regulators and other capital market participants should acknowledge that companies may differ in their use of Corporate Governance mechanisms for various reasons, including differences in ownership dispersion and international orientation.

Keywords: Corporate Governance, Transparency, Board Member Independence, Two Tier Board Structure, Ownership Dispersion, Internationalisation. 


\section{INTRODUCTION}

The preamble of the "OECD Principles of Corporate Governance" declares that Corporate Governance should be considered as a key element in improving economic efficiency and growth as well as enhancing investor confidence (e.g., OECD, 2004). In accordance with the arguments adduced by OECD, it has been suggested that the capital market will reward companies exercising good Corporate Governance, which will be reflected in market-based performance measures (Gompers et al., 2003, Klein et al., 2005, Yermack, 1996). For the companies this would be picked up in the form of lower capital costs - indirectly through improved risk ratings and thereby better credit and loan possibilities or directly through larger propensity to invest in the company shares (Botosan and Plumlee, 2002, Leuz and Verrecchia, 2000, Anderson et al., 2004). Good Corporate Governance has also been linked to improved economic efficiency, which will be reflected through operational and financial performance measures (Core et al., 2006, Dulewicz and Herbert, 2004, Erhardt et al., 2003).

Many prior studies have examined the link between particular Corporate Governance properties and corporate performance, and a number of mitigating factors have been suggested as explanations for different findings. Some studies have attempted to deal with the mitigating factors by including such typical control variables as company size, risk and industry (e.g., Gompers et al., 2003, Yermack, 1996). In country comparisons the regulation regiment has also been included (e.g., Chua et al., 2007). Some studies are also referring to measurement problems derived from the econometric properties of the 
models and variables included, i.e. realizing that Corporate Governance is a complex system of inter-related issues (e.g., Larcker et al., 2007, Cremers and Nair, 2005). However, despite the numerous studies and attempts it has not been possible to provide empirical findings confirming a single powerful relationship between good Corporate Governance and good company performance. This forms the basis for our research question: Is it more important to reduce asymmetric information through particular Corporate Governance mechanisms for some listed companies than for others?

A number of studies have looked at the impact of international capital mobility on convergence of Corporate Governance models (Richard and Sofia, 2000) or convergence of Financial Accounting models (Gray et al., 1995, Forker and Green, 2000). In a comparison of Germany, France, Spain, and Italy, the main finding by Richard and Sofia (2000) is that convergence toward one Corporate Governance model is not as strong as expected when considering the mobility of capital. They argue that the politics of financial reform may counteract the convergence and that countries are susceptible to various types of international pressure. Forker and Green (2000) expand the comparison of Corporate Governance models to the role of accounting model choice. They recommend that applying different models will better suit the interests of investors across different styles of Corporate Governance.

The purpose of this study is to examine how "ownership dispersion" and "international orientation" of listed companies affect two of the prime Corporate Governance mechanisms, namely "transparency" and "board independence". It is important to 
understand the circumstantial nature of these mechanisms, because previous studies have suggested that the relationship between good Corporate Governance and good corporate performance may be mitigated by company specific circumstances (e.g., Bradley, 2004, Brown and Caylor, 2006, Eng and Mak, 2003).

In line with the OECD principles we suggest that the overall transparency of a company is a prime Corporate Governance mechanism which is likely to reduce agency costs as better information becomes available to the finance providers. The consequence is a reduction in asymmetric information. In their review of empirical disclosure literature Healy and Palepu (2001) argue that corporate disclosure (mandatory as well as voluntary) is critical for the functioning of an efficient market. Hence, in order to reduce capital costs a high level of transparency is expected for companies with more dispersed shareholders and international ownership. Companies engaging in international competition for capital will adopt a level of transparency which extends beyond national interests (i.e., higher levels of disclosure). In contrast, closely held companies do not have to rely on external disclosures to the same extent. Our findings are based on a Danish dataset which includes 100 companies listed on the Copenhagen Stock Exchange. Our findings suggest that transparency is a more important Corporate Governance mechanism for companies with an international orientation, while differences in ownership dispersion do not affect the use of the transparency mechanism.

The independence of board members is also a prime Corporate Governance mechanism identified in the OECD principles. Healy and Palepu (2001) describe the board of 
directors as one of the mechanisms for reducing agency problems (see also Heslin and Donaldson, 1999). We suggest that board independence is likely to reduce agency costs as better control is exercised on behalf of the finance providers. Hence, in order to reduce capital costs a high degree of independence is expected for companies with dispersed shareholders and international ownership.

Board independence has been a key issue in the unitary (one-tier) board systems as found in the Anglo-American settings. Here the recommendations found in various Corporate Governance Codes have been related to the number and function of Non-Executive Directors (NEDs). Even though there are structural differences between two-tier and unitary board systems, there are also similarities (e.g., both systems recognize a supervisory and a managerial function). While the supervisory role of the board is formalized as an engrained part of the two-tier system, board member independence is none the less part of Corporate Governance recommendations in the two-tier contexts of EU countries such as Germany, Austria, the Netherlands and Denmark. The signalling of "board independence" may be compared to the chosen "level of transparency" in the sense that both provide information for external purposes. This constitutes a distinct difference between the two-tier system, where internal supervision is defined as part of the board system, and the one-tier system, where board independence often is considered as an internal Corporate Governance measure.

Our findings suggest that board independence is a more important Corporate Governance mechanism for companies with widely dispersed ownership and with an international 
orientation, but that the importance under the first circumstances is more marked than under the latter. Our study provides insight into valid reasons for differences in compliance to Corporate Governance codes. Because companies have different agendas they may differ in their use of Corporate Governance mechanisms. This insight is an important enabler for fair assessments of company differences of "good" Corporate Governance.

The remainder of the paper is structured in the following way. In the second section we provide the motivation for the hypotheses by examining prior literature. In the third section we describe the methodology, i.e., the particularities of the Danish dataset and the model development. In the fourth section we provide the analyses and results in accordance with the two Corporate Governance mechanisms considered in this study. Finally we conclude the paper in the fifth section.

\section{MOTIVATION AND LITERATURE REVIEW}

In this section we provide the motivation and literature review as the basis for developing hypotheses on two sets of Corporate Governance mechanisms, namely transparency in the first subsection and the board independence in the second subsection.

\section{Transparency as Corporate Governance Mechanism}

The perspectives of Corporate Governance are abundant. In a review of previous Corporate Governance literature Ho identifies no less than 16 conceptual models 
including such models as the Finance Model, the Stewardship Model, the Stakeholder Model, the Political Model, etc. (Ho, 2005, 214-216). The focal points of these models differ, although they often overlap (Clarke, 2004, Nicholson and Kiel, 2007). A holistic view on the interrelated factors determining good Corporate Governance may be needed (Ho, 2005). However, this must be supported by knowledge of the individual relationships between such factors. In order to obtain knowledge of factors determining the nature of the relationship between good Corporate Governance and good corporate performance, testable hypotheses must be derived directly from theories supporting the underlying relationships between Corporate Governance variables.

In the context of Corporate Governance, the Finance Model lends itself to deriving such testable predictions. The key issue of the Finance Model is how to assure that suppliers of finance to corporations get an appropriate return on their investment. This is a classical agency problem with a focus on reducing agency costs. According to this model, disclosure of relevant and reliable information is all important for the functioning of an efficient capital market (Leuz and Verrecchia, 2000). The information may be mandatory information, e.g. financial statements, or voluntary in the form of additional financial or non-financial information. The effect of increased disclosure is improved transparency, which is identified as one of the main aims of Corporate Governance provisions (OECD, 2004, section V):

"The corporate governance framework should ensure that timely and accurate disclosure is made on all material matters regarding the corporation, including the financial situation, performance, ownership, and governance of the company". 
The importance of disclosure level has been examined from a cost-of-capital viewpoint (Daske, 2006, Gietzmann and Ireland, 2005, Botosan and Plumlee, 2002, Leuz and Verrecchia, 2000). While the theoretical relationship between disclosure and the cost of capital is expected to be negative, previous empirical evidence provides mixed results. In contrast to a prior study by Botosan, Botosan and Plumlee (2002) find that the cost of equity capital decreases with the annual report disclosure level. However, they also find that firms' cost of capital increases with timely disclosures.

The mixed findings suggest the need to carefully include all important variables and appropriate operational measures in this type of research (Gietzmann and Ireland, 2005, Williams, 2004, Gelb and Zarowin, 2002). Gietzmann and Ireland (2005) introduce an alternative measure of timely disclosure that attempts to capture quality rather than quantity of strategic disclosures. By using this measure they do find the expected negative relationship. Another study by Leuz and Verracchia (2000) supports this relationship. They use the change from national (German) reporting regime to international (IAS/IFRS or US-GAAP) as a measure for increased disclosure and find the expected negative relationship to the applied proxy for the information asymmetry component of the cost of capital, in this case the bid-ask spread and trading volume. In a follow-up study by Daske (2006) based on German companies for the period 1993-2002, the expected lower cost of equity capital for firms applying IAS/IFRS or US-GAAP is not found. In fact, the expected cost of equity capital seems to increase rather than decrease under the international accounting regime. 
According to Klein et al. (2005) the elements of measured governance are not equally important, and the effects of governance do differ by ownership category. In fact ownership structures seem to matter for a number of Corporate Governance issues examined in prior studies (Dwivedi and Jain, 2005, Gorton and Schmid, 1999, Klein et al., 2005, Krivogorsky, 2006, Seifert et al., 2005).

Dwivedi and Jain (2005) examine 340 large, listed Indian firms for the period 1997 to 2001. They use Tobin's Q as a proxy for the firms' performance in relation to several Corporate Governance parameters including board size, directors' shareholdings, institutional and foreign shareholding as well as the extent of public shareholding. They find higher performance related to foreign shareholding (predicted direction supported), but not to institutional shareholding (predicted direction not supported). The predicted direction of lower performance owing to dilution of control is also supported in the case of higher ratio of public shareholding (i.e., fragmented shareholding or ownership dispersion). Gorton and Schmid (1999) study Austrian cooperative banking, an organizational form in which the ownership structure is exogenous. They find that company performance declines as the number of cooperative members increases, corresponding to a greater separation of ownership and control. Using data from 87 European firms, which were foreign U.S. registrants during 2000-2001, Krivogorsky (2006) examines the empirical validity of claims that the composition of boards of directors and ownership structures affect firms' profitability ratios (ROE, ROA, MTB). Results indicate a strong positive relation between the level of relational ownership and profitability ratios, and between the portion of independent directors on the board and 
profitability ratios.

One way to look at the importance of disclosure in order to attract international capital is provided by Gray et al. (1995). In this study they looked at the annual report disclosure practices of 116 US and 64 UK multinationals. They found significant differences in financial reporting behaviour between internationally and domestically listed multinational corporations and noted that the international listing effect is especially important in respect of strategic information disclosures. In an international comparison Chua et al. (2007) find that both Corporate Governance regime and the degree of capital market openness play a significant role in explaining corporate valuation. The reason is that restricted capital market regimes discourage international investments while open capital markets promote a more efficient risk sharing among international investors, which results in lower costs of capital and higher corporate valuation (Chua et al., 2007, 37).

Prior studies suggest that the relationship between good Corporate Governance and good corporate performance may be mitigated by company specific circumstances such as ownership structure (i.e., ownership dispersion) and capital market orientation (i.e., international orientation). In figure 1 we identify the relationships investigated in this study.

\footnotetext{
*** Insert Figure $1 * * *$
} 
In line with the OECD principles we suggest that the overall transparency of a company is a prime Corporate Governance mechanism which is likely to reduce agency costs as better information becomes available to the finance providers. The consequence is a reduction in asymmetric information and for the companies a reduction in capital costs. Accordingly, the Finance Model will predict differences in terms of ownership structure and capital market orientation. Closely held companies do not have to rely on external disclosures to the same extent as companies with dispersed ownership structure. International competition for capital by companies will suggest a level of transparency extending beyond national interests (i.e., higher levels of disclosure). Hence, the Finance Model will predict a higher level of transparency for companies oriented toward (1) dispersed shareholders and (2) international ownership. We suggest the following hypotheses:

H1: Companies with dispersed ownership will have a higher level of Corporate Governance transparency.

H2: Companies with international orientation toward the capital market will have a higher level of Corporate Governance transparency.

\section{The Independence of Boards as Corporate Governance Mechanism}

From an agency perspective, the presence of independent board members is important in order to reduce the conflict of interest between providers of finance and company 
management (Brennan, 2006, Ingley and Van der Walt, 2004, Rhoades et al., 2001).

Hence, the independence of boards is a prime Corporate Governance mechanism (OECD, 2004, section VI):

"The corporate governance framework should ensure the strategic guidance of the company, the effective monitoring of management by the board, and the board's accountability to the company and the shareholders."

Specific Corporate Governance issues such as "board member independence" (Gani and Jermias, 2006, Klein et al., 2005, Fosberg and Nelson, 1999), "board size and composition" (Rose, 2005, Bebchuk and Cohen, 2005, Oxelheim and Randøy, 2003, Yermack, 1996) and "board member and management compensation" (Brunello et al., 2001, Randøy and Nielsen, 2002) have been recognized as key elements in the Corporate Governance debate.

A study by Gani and Jermias (2006) ties board independence to company performance by looking at different strategies. They find that board independence has a significantly higher positive effect on performance for firms pursuing a strategy of cost efficiency than for those pursuing a strategy of innovation. Klein et al. (2005) analyze the relationship between firm value (proxied by Tobin's Q) and Corporate Governance indices for a sample of 263 Canadian firms. In contrast to the study by Gani and Jermias (2006) they find no evidence that board independence has any positive effect on company performance.

The possibility of overlapping $\mathrm{CEO} /$ chair function is part of the discussion of the optimal board composition. Fosberg and Nelson (1999) looked at explanations for a dual 
leadership structure, i.e., why some firms have different persons holding the chairman of the board and CEO positions. In fact they found evidence supporting both the dual leadership structure in line with agency problem theory and in line with the normal succession theory. Hence, separating the CEO and chairman of the board positions will reduce the agency costs. In this study they found a positive relationship between company performance and separation of the leadership positions under circumstances in which the leadership structure changed.

The size of the board may be one intermediate factor influencing company performance. Yermack (1996) found evidence consistent with theories that small boards of directors are more effective. In a study of 452 large U.S. industrial corporations between 1984 and 1991 he found an inverse association between board size and firm value (proxied by Tobin's Q). However, this finding was not supported in a study by Rose (2005) for Danish listed companies. His findings suggested that board size, proportion of insiders, and positions held by board members in other firms do not have any significant impact on performance (also proxied by Tobin's Q). In terms of board composition, only the average age of the board had a significantly negative impact on performance. The interpretation by Rose (2005) is that board structure only plays a crucial role when a firm is in financial trouble or faces a major threat.

The protection of board and management against change from e.g. hostile takeovers can be engrained in the company structure through provisions in company charter or bylaws. Bebchuk and Cohen (2005) examined such protective mechanisms and found that 
"insulated boards" were associated with an economically meaningful reduction in firm value (proxied by Tobin's Q).

The orientation toward foreign board memberships can be part of a focus on the international capital market for listed companies. Oxelheim and Randoy (2003) examined the effect of foreign (Anglo-American) board membership on corporate performance (proxied by Tobin's Q). Using a sample of firms with headquarters in Norway or Sweden they found a significant positive relationship between performance and foreign membership of boards. They suggest that the superior performance reflects the fact that these companies have successfully broken away from a partly segmented domestic capital market and that this enhances a positive reputation in the financial market.

Board and ownership structures have also been tied to CEO compensation. Randøy and Nielsen (2002) examined the relationship among CEO compensation and Corporate Governance arrangements within the Scandinavian countries of Norway and Sweden. They looked at 224 listed companies in the two counties; 120 from Norway and 104 from Sweden. The empirical evidence from both Norway and Sweden suggests that CEO compensation is positively related with board size, foreign board membership, and market capitalization. A significant negative relationship is found between CEO compensation and CEO ownership. In addition, no significant relationship is found between CEO compensation and company performance or CEO tenure. Brunello et al. (2001) examined a sample of Italian firms and found a low relationship between CEO compensation and company performance. However, they did find a higher than average 
pay-performance sensitivity in foreign-owned firms, in listed firms, and in firms affiliated to a multinational group.

As mentioned in the introduction the supervisory role of the board is formalized as an engrained part of the two-tier system. Board member independence is an explicit part of the Corporate Governance recommendations in the two-tier context of countries such as Germany, Austria, the Netherlands, and Denmark. In the Danish Corporate Governance Code (CSE, 2005, section V.4) it is recommended that at least half of the supervisory board members elected by the general meeting be independent persons and that the members of the executive board of a company not become members of the board. The CSE (2005) code identifies the conditions of independence in the following way, i.e., independent members may not: (a) be an employee of the company or have been employed by the company within the past five years, (b) be or have been a member of the executive board of the company, (c) be a professional consultant to the company or be employed by, or have a financial interest in, a company which is a professional consultant to the company, or (d) have some other essential strategic interest in the company other than that of a shareholder. Furthermore, any person related, in terms of business or in any other way, to the company's major shareholder is not regarded as an independent person. The signalling of "board independence" may be compared to the chosen "level of transparency", in the sense that both provide information for external purposes. This is a distinct difference between the two-tier system, where internal supervision is defined as part of the board system (Rose, 2005), and the one-tier system, where board independence often is considered as an internal Corporate Governance measure (de 
Andres et al., 2005, Kang et al., 2007).

Similar to "transparency", the "independence of board members" is a prime Corporate Governance mechanism identified in the OECD principles. In the two-tier context, board member independence may be measured in several ways including whether the board member represents a large shareholder (not independent) and whether directors are members of the board (not independent). We suggest that board independence is likely to reduce agency costs as it ensures improved control on behalf of the finance providers. Accordingly, the Finance Model predicts a higher degree of independence for companies oriented toward (1) dispersed shareholders and (2) international ownership, see figure 1. Hence, we suggest the following hypotheses:

H3: Companies with dispersed ownership will have a higher degree of board independence.

H4: Companies with international orientation toward the capital market will have a higher degree of board independence.

\section{METHODOLOGY}

In this section we first describe the dataset and the variables applied. Second we present the models used to test the hypotheses developed in the previous section. Finally we provide some initial descriptive statistics. 


\section{Dataset and Variables}

The dataset contains Corporate Governance related attributes and size and performance indicators for 100 Danish companies listed on the Copenhagen Stock Exchange. The data derive mainly from information in the 2004 annual reports, articles of association, and company websites. International guidelines such as the OECD Corporate Governance Guidelines (OECD, 2004) as well as the Danish Corporate Governance code have inspired the selection of the Corporate Governance attributes (CSE, 2005). The Corporate Governance attributes are part of a larger Danish dataset covering the development in different Corporate Governance issues during the period 2002 to $2005^{1}$.

In total we collected information on 140 company specific issues of which 127 variables relate to Corporate Governance properties and 13 variables relate to size and performance $^{2}$, see table 1 . We use 84 of the Corporate Governance variables to construct measures for the two Corporate Governance mechanisms:

- The total disclosure level, CGDISCLEVEL, a measure for transparency based on a simple addition of 82 categorical variables from the dataset including attributes covering the following factors: General CG-Policy and information; Information on strategy, mission, profits, expectations, and risk management; Investor relations policy (IR-Policy); Shareholder meeting procedures; Board activity, Board composition; Compensation of management and board, Management profile; Auditor compensation and activity; and Ownership structure and voting power.

- The independence of the board measured by the proportion of board members not 
representing large shareholders, CGBOARDLARSH ${ }^{3}$.

\section{** Insert Table $1 * * *$}

We examine the effect on the Corporate Governance mechanisms through our four hypotheses with independent variables including ownership dispersion (four variables), international orientation (four variables), and size and performance (four control variables). The predicted direction of the ownership dispersion is identified in figure 1 . The Financial Model predicts that the Corporate Governance mechanisms will be positively linked to ownership dispersion. The independent variables introduced as proxies for ownership dispersion include the absence of large shareholders, the absence of more share-classes, the presence of ownership restrictions, and the level of institutional ownership.

\section{Ownership dispersion:}

- No large shareholder(s) variable, ODLARGESH, measures by a categorical variable whether shareholder(s) have more than $20 \%(=0)$ or no large shareholders exists $(=1)$. The absence of large shareholders reflects a more dispersed ownership.

- The company only has one share-class variable, ODSHARECLASSES, measures by a categorical variable whether the company holds more than one share-class $(=0)$ or only one share-class is available $(=1)$. The absence of more share-classes reflects a more dispersed or less controlled ownership.

- Ownership-restrictions on capital and/or votes variable, ODRESTRICTIONS, 
measures by a categorical variable whether restrictions exist $(=1)$ or do not exist $(=0)$. The presence of ownership restrictions reflects a more dispersed ownership.

- The share of the company shares owned by institutional investors variable, ODINSTITUTIONALINV, measures the part of the shares owned by institutional investors. A relatively higher proportion of institutional ownerships reflects a more dispersed or less controlled ownership, since no institutional investor usually seeks considerable influence.

As identified in figure 1, the Financial Model predicts that the Corporate Governance mechanisms will be positively linked to internationalisation. The independent variables introduced as proxies for internationalisation include the extent of foreign shareholding, voluntary IFRS adoption, proportion of foreign board members, and extent of international board member experience.

\section{Internationalization:}

- The foreign shareholders' part of equity, INFOREIGNSH, measures the proportion of equity owned by foreign shareholders.

- The IFRS first adopters, INIFRSFIRST, measures whether the company has chosen to voluntarily adopt international standards in the accounting statements $($ yes $=1)$.

- The foreign board members variable, INFOREIGNBM, measures whether the board has foreign members (yes $=1$ ).

- The board members with international experience variable, ININTLEXPBM, 
measures whether some board members have international experience (yes=1), where international experience is defined as executive director for international companies or foreign subsidiaries.

Our decision to use data from 2004 was supported by the condition identified by the INIFRSFIRST variable. In Denmark the listed companies had the option to voluntarily disclose the accounting information for the financial year 2004 in accordance with the IFRS/IAS standards or to disclose in accordance with Danish regulations and standards (while IFRS/IAS disclosure of consolidated financial statements is mandatory for the financial year starting January $1^{\text {st }} 2005$ ).

Prior studies have examined the relationship between Corporate Governance and corporate performance using external measures such as Tobin's $\mathrm{Q}$ and share price volatility and/or internal measures such as Return on Assets (ROA) and Return on Invested Capital (ROIC). Measures of size and risk have also been applied as control variables in a number of studies due to the possible endogeneity effect of these variables. We have collected 13 control and performance variables as possible candidates. We chose a representative for each of these four factors, i.e., EBITDA and Price-to-Book as internal and external performance measures respectively, and Beta and Total Capital as measures for risk and size respectively.

Performance, risk and size: 
- The Earnings before Income Tax, Depreciation and Amortization-Margin variable, PFEBITDA, measures the profitability of the company. The measure is an income statement originated measure independent of the size of the companies.

- The Price to Book ratio, PFPTB, measures the market assessment of the company value relative to the company's financial statements.

- The beta-value, PFBETA, measures the actual systematic risk attributed to the company.

- The Total Capital variable, PFTOTALCAPITAL, measures the total capital of the company, and is as such also a company size proxy.

\section{Models}

In order to examine the relationships identified in figure 1 we use linear regression (OLS) models, i.e., one for each of the hypotheses stated in section 2. The models are the end product of an exploratory process, where several Corporate Governance attribute variables as well as performance measures were introduced, and others were omitted in order to reduce potential multicollinearity issues as much as possible ${ }^{4}$. The models for the transparency mechanism $(\mathrm{H} 1$ and $\mathrm{H} 2)$ are specified as follows:

(1) CGDISCLEVEL $=\alpha_{0}+\alpha_{1}$ ODLARGESH $+\alpha_{2}$ ODSHARECLASSES + $\alpha_{3}$ ODRESTRICTIONS $+\alpha_{4}$ ODINSTITUTIONALINV $+\alpha_{5}$ PFEBITDA + $\alpha_{6}$ PFPTB $+\alpha_{7}$ PFBETA $+\alpha_{8}$ PFTOTALCAPITAL $+\varepsilon$ 


$$
\begin{aligned}
& \text { CGDISCLEVEL }=\beta_{0}+\beta_{1} \text { INFOREIGNSH }+\beta_{2} \text { INIFRSFIRST }+ \\
& \beta_{3} \text { INFOREIGNBM }+\beta_{4} \text { ININTLEXPBM }+\beta_{5} \text { PFEBITDA }+\beta_{6} \text { PFPTB }+ \\
& \beta_{7} \text { PFBETA }+\beta_{8} \text { PFTOTALCAPITAL }+\xi
\end{aligned}
$$

In the first model we identify the total disclosure level (CGDISCLEVEL) as a function of ownership dispersion (four variables) and the mitigating factors related to performance, risk and size of the companies (4 variables). The predicted effect of internationalisation is introduced in a similar manner in the second model.

The models for the board independence mechanism (H3 and H4) are specified as follows:

$$
\begin{aligned}
& \text { CGBOARDLARSH }=\alpha_{0}+\alpha_{1} \text { ODLARGESH }+\alpha_{2} \text { ODSHARECLASSES }+ \\
& \alpha_{3} \text { ODRESTRICTIONS }+\alpha_{4} \text { ODINSTITUTIONALINV }+\alpha_{5} \text { PFEBITDA }+ \\
& \alpha_{6} \text { PFPTB }+\alpha_{7} \text { PFBETA }+\alpha_{8} \text { PFTOTALCAPITAL }+\varepsilon
\end{aligned}
$$

$$
\begin{aligned}
& \text { CGBOARDLARSH }=\beta_{0}+\beta_{1} \text { INFOREIGNSH }+\beta_{2} \text { INIFRSFIRST }+ \\
& \beta_{3} \text { INFOREIGNBM }+\beta_{4} \text { ININTLEXPBM }+\beta_{5} \text { PFEBITDA }+\beta_{6} \text { PFPTB }+ \\
& \beta_{7} \text { PFBETA }+\beta_{8} \text { PFTOTALCAPITAL }+\xi
\end{aligned}
$$

We use the variable CGBOARDLARSH as a proxy for board independence in model three (the effect of ownership dispersion measured by four variables) and model four (the effect of internationalisation measured by four variables). The models all have the same structure, i.e., controlling for the same PF-variables for performance, risk and size. 


\section{Descriptive Statistics}

We provide descriptive statistics for the sample in table 2. First, we notice that the Corporate Governance mechanisms are applied differently by the companies. The average disclosure level for the 100 companies is 52.5 percent with a minimum of 28.1 and a maximum of 91.5 percent of the 82 disclosure items possible. The board independence measure is 83.7 percent on average, i.e., indicating that most board members in Danish listed companies do not represent large shareholders (although the proportion varies between zero and 100). Second, we notice that the medians for the two dependent variables are close to the means, thus implying the absence of skewness in these measures.

\section{** Insert Table $2 * * *$}

We distinguish between continuous and categorical measures for our independent variables (ownership dispersion and internationalisation). The independent variables show a noticeable tendency towards skewness, i.e., means are above medians for the two continuous measures ODINSTITUTIONALINV and INFOREIGNSH and we have unequal proportions for all categorical measures of ownership dispersion and internationalisation for the 100 companies. Also worth noting is the relation between the two variables INFOREIGNBM and ININTLEXPBM, both of which are measures for international experience in the boards. The first measures whether the companies have board member(s) of foreign origin, while the latter measures whether some board 
members have international experience. In this context international experience is defined as being executive director for international companies or foreign subsidiaries (63 companies). In about half of these companies the international experience is represented by having a board member of foreign origin (32 companies).

All PF-variables controlling performance, risk and size are continuous measures. In many contexts performance is viewed as a combination of risk and return. In this study we apply the measures for the company-specific beta, the earnings before interest, tax, depreciation and amortization (EBITDA), and the Price to Book ratio (PTB) together with the size measure of total capital. Since the beta value 1.0 expresses that the company has a risk precisely matching the market risk, our sample in general represents a group of companies with risk below the market risk (average beta 0.527). However, the sample includes 12 biotech and pharmaceutical companies. Not surprisingly they are the source of most of the extreme data to the sample (maximum beta of 1.760), but on the other hand they do not represent a disproportionately large part of the total number of companies.

\section{** Insert Table $3 * * *$}

We provide an overview of the contemporaneous Pearson correlations between the various variables in table 3. The correlations support the relevance and structure of the models applied to examine the four hypotheses. First, we notice the absence of significant correlation between the two dependent variables CGDISCLEVEL and CGBOARDLARSH, i.e., suggesting that we are dealing with different Corporate Governance mechanisms. Second, the ownership dispersion measures are generally not 
correlated with the internationalisation measures. This suggests that the independent variables measure different Corporate Governance properties. Exceptions are the positive correlation between the extent of large shareholders ODLARGESH and foreign shareholders INFOREIGNSH (coefficient of 0.200 significant at the five percent level) and the negative correlation between ownership restrictions ODRESTRICTIONS and international board experience ININTLEXPBM (coefficient of -0.200 significant at the five percent level).

Third, the ownership dispersion measures ODLARGESH, ODSHARECLASSES and ODRESTRICTIONS are significantly correlated in the positive direction. We notice that institutional ownership is negatively correlated with the remaining three measures for ownership dispersion, although only significant (at the one percent level) for ODSHARECLASSES. Fourth, the internationalisation measures INFOREIGNSH, INIFRSFIRST, INFOREIGNBM, and ININTLEXPBM are all positively correlated, although not all significant. Fifth, correlations between dependent variables and independent measures are significant, but differences between the two sets of independent measures are suggested. The effects on each of the Corporate Governance mechanisms are examined in the next section. Finally we recognise the variation of importance of the control variables PFEBITDA, PFPTB, PFBETA, and PFTOTALCAPITAL. There is no clear pattern of correlations between the individual PFvariables and the remaining variables. 


\begin{abstract}
ANALYSES
In this section we present the results of the OLS regression analyses in three subsections. In the first and second subsection we examine the hypotheses related to transparency and board independence as Corporate Governance mechanisms. In the third subsection we present findings based on additional robustness tests.
\end{abstract}

\title{
Results on Transparency as Corporate Governance Mechanism
}

We present the results on transparency as Corporate Governance mechanism in table 4. The first model tests the effect on transparency by ownership dispersion variables and the mitigating factors related to performance, risk and size of the companies. While the overall model is significant at the one percent level (F-value of 3.55), none of the proxies for ownership dispersion are significant at the ten percent level, and they take the opposite directions of what we had predicted. Hence, H1 is not supported by the dataset. Ownership dispersion does not seem to be associated with a high Corporate Governance disclosure level. In relation to possible mitigating factors, the model identifies the importance of the size-variable PFTOTALCAPITAL, which is significant at the one percent level. This suggests that larger companies are also the ones capable of using the resources for providing transparency. The size effect is a consistent finding in prior studies of the relationship between Corporate Governance and corporate performance (Adjaoud et al., 2007, Berger et al., 2005, Brown and Caylor, 2006, Haniffa and Hudaib, 2006). 


\section{** Insert Table $4 * * *$}

The second model in table 4 tests the effect on transparency by international orientation variables and the mitigating factors related to performance, risk and size of the companies. The overall model is significant at the one percent level (F-value of 8.53). We find that each of the four proxies for internationalisation has significant coefficients in the predicted direction, thus $\mathrm{H} 2$ is supported by the dataset. This suggests that the more the company is internationally oriented toward the capital market, the more is the company likely to choose a high level of Corporate Governance transparency. The proxies for internalisation are interrelated, but the model has no problem with multicollinearity. International board experience (ININTLEXPBM) and the IFRS first-adopters (INIFRSFIRST) provide the strongest effect on transparency, while foreign shareholders (INFOREIGNSH) and foreign board members (INFOREIGNBM) have slightly less

effect (both with significance levels at ten percent ${ }^{5}$ ). This importance of international orientation as a determinant for the Corporate Governance transparency level is in line with the finding reported in prior studies (Dwivedi and Jain, 2005, Gray et al., 1995, Oxelheim and Randøy, 2003).

We find that the size effect (PFTOTALCAPITAL) is important in both of the models relating to transparency. In the second model, our risk measure PFBETA is significant at the five percent level, while the two performance variables PFEBITDA and PFPTB are non-significant. However, the sign for the estimated coefficient for the return variable PFEBITDA is negative, which could indicate that the less well-performing companies are 
more likely to choose more Corporate Governance transparency than vice versa. This would be in line with the expected relationship between Corporate Governance and declining firm performance (Evans et al., 2002) and supported by findings reported by Rose (2005) in a previous study of listed Danish Companies.

A comparison of the two models, reflecting $\mathrm{H} 1$ and $\mathrm{H} 2$ respectively, shows higher overall significance as well as more significant coefficient estimates for the independent variables for $\mathrm{H} 2$. The implication is that transparency could be seen as a positive Corporate Governance mechanism in companies with an international orientation, but not necessarily in companies with more dispersed ownership.

\section{Results on the Independence of Boards as Corporate Governance Mechanism}

We present the results on board independence as Corporate Governance mechanism in table 5. The third model tests the effect on board independence by ownership dispersion variables and the mitigating factors related to performance, risk and size of the companies.

\section{** Insert Table $5 * * *$}

The importance of ownership dispersion is supported by the F-value of 6.06 for the model testing $\mathrm{H} 3$ (significant at the one percent level). The proxies for ownership dispersion differ in importance, i.e., the presence of large shareholders (ODLARGESH) is 
significant at the 1 percent level, while the presence of share restrictions (ODRESTRICTIONS) and the relative absence of institutional investors (ODINSTITUTIONALINV) are both significant at the five percent level. The number of share classes (ODSHARECLASSES) is irrelevant in this context. The implication of our finding is that a high proportion of independent board members could be conceived as a positive Corporate Governance mechanism when capital is more dispersed between owners. The effect of ownership dispersion may help explain opposite findings reported in previous studies on the relationship between board independence and firm performance (e.g., Gani and Jermias, 2006, Klein et al., 2005).

The effect on board independence should also be considered in contrast to the rejection of H1, namely the absence of a relationship between ownership dispersion and overall Corporate Governance transparency as a Corporate Governance mechanism. We also notice that we have no size effect (PFTOTALCAPITAL) as a mitigating factor for board independence. Instead we have a positive influence by risk (PFBETA significant at the five percent level) and a negative influence by market performance (PFPTB significant at the five percent level) on board independence as a Corporate Governance mechanism.

The model testing $\mathrm{H} 4$ is significant at the one percent level (F-value of 3.05), while only two of the proxies for internationalisation (INFOREIGNBM and INIFRSFIRST) have significant coefficients. Overall, this suggests a less convincing relationship between internationalization and the board independence mechanism. This is also clear when we compare the finding with the test of the transparency mechanism. The F-value of the 
model testing the importance of internationalization is considerable higher for $\mathrm{H} 2$ than for H4, i.e. an F-value of 8.53 for transparency as Corporate Governance mechanism as compared to an F-value of 3.05 for board independence as Corporate Governance mechanism. This comparison identifies a relatively low signalling power of "board independence" as compared to the stronger "transparency" as external Corporate Governance measures in the context of the two-tier board system.

In relation to the effect of internationalisation on board independence we find mitigating factors related to performance (significant negative coefficient for PFPTB and significant positive coefficient for PFEBITDA), risk (significant positive coefficient for PFBETA), but not to size (PFTOTALCAPITAL) of the companies. Gani and Jermias (2006) suggest that board independence should not be thought of as a panacea to increase any firm's performance. Their observation is made in a one-tier board structure context, where the impact of board independence is seen as an internal instrument in relation to different strategic business challenges. This message seems to hold in the present two-tier context with "board independence" carrying an external Corporate Governance role of signalling to the outside world. We also observe that the sizes of the estimated coefficients for the PF-variables are generally at higher levels in relation to board independence than in relation to Corporate Governance transparency. International orientation affects the Corporate Governance mechanisms, but we do not find a clear pattern for the mitigating factors of performance, risk and size. 


\section{Additional Robustness Results}

In this section we provide additional findings based on a closer examination of the independent variables including tests for possible interaction effects. One of the interesting aspects from the analyses in the previous sections concerns the crossing conclusions, i.e., the importance of international orientation for transparency $(\mathrm{H} 2)$ and the ownership dispersion for board independence (H3). Hence we made additional robustness tests combining the measures for ownership dispersion and international orientation. These analyses were carried out in different ways, since a simple total combination would leave us with a total model including 12 independent variables, plus 10 possible interaction combinations of the four ownership dispersion variables and the four internationalisation variables. First we analysed the effect on transparency by applying backward stepwise regression in order to identify the most representative combination of ownership dispersion and internationalisation variables. We applied similar procedures for a new board independence model. In each of the new models the four control variables were retained. The two variables ODLARGESH and INFOREIGNBM are the most promising combination of ownership dispersion and internationalisation variables. However, the resulting combined models are less powerful than the models testing for the separate effects (untabulated results).

For this reason we decided to test an alternative approach for the combined models. We constructed two composite variables, one for ownership dispersion and one for internationalisation. In order to add the outcome of the separate independent variables, 
we transformed the two continuous variables ODINSTITUTIONALINV and ININTLEXPBM into categorical variables ${ }^{6}$. Then we simply added the outcome of the four categorical variables for ownership dispersion and internationalisation respectively into the two variables COMPOSITE OD and COMPOSITE IN.

\section{** Insert Table $6 * * *$}

In table 6 we present the results of these ownership dispersion and internationalisation effects on Corporate Governance transparency and board independence using the two composite variables together with a variable COMPOSITE ODxIN describing the interaction between the two. The results show that Corporate Governance transparency is especially affected by international orientation while board independence is especially affected by ownership dispersion. We find no support for interaction effects in neither the model for transparency nor the model for board independence. The findings based on these additional analyses altogether support our overall results in favour of $\mathrm{H} 2$ and $\mathrm{H} 3$ as discussed in the previous sections.

\section{CONCLUSIONS AND IMPLICATIONS}

In line with the OECD principles, we suggest that "transparency" and "board independence" are prime Corporate Governance mechanisms which are likely to reduce asymmetric information issues and hereby reduce agency costs as better information 
becomes available to the finance providers. It is therefore very relevant that most countries have included these mechanisms as explicit elements of national Corporate Governance codes. It is important to understand the circumstantial nature of these mechanisms, because previous studies have suggested that the relationship between good Corporate Governance and good corporate performance may be mitigated by company specific circumstances (e.g., Bradley, 2004, Brown and Caylor, 2006, Eng and Mak, 2003). Overall we query whether reduction of asymmetric information through particular Corporate Governance mechanisms is more important for some listed companies than for others.

We used the Finance Model (agency theory) to predict differences between companies in their use of transparency and board independence as Corporate Governance mechanisms. A high level of Corporate Governance transparency was predicted for companies oriented toward dispersed shareholders (not supported by our findings) and with international orientation (supported). Similarly, a high degree of independence was predicted for companies oriented toward dispersed shareholders (supported by our findings) and international orientation (supported with less importance). We used several measures for each factor and in order to control for mitigating factors, we also included company specific measures of risk, size and performance in all models.

The findings in our study are based on a Danish dataset which includes 100 companies listed on the Copenhagen Stock Exchange. One of our main findings is the importance of Corporate Governance transparency for Danish companies with an international 
orientation. International competition for capital has been found to influence the level and quality of corporate disclosure in other countries such as the US and the UK (Gray et al., 1995), Germany, France, Spain, and Italy (Richard and Sofia, 2000) as well as Norway and Sweden (Oxelheim and Randøy, 2003). Obviously, there is not one single reason for higher levels of disclosure in conformance with Corporate Governance codes. Our findings for Danish companies support results in the prior studies that international orientation by listed companies is mitigated by size effects. One interpretation of this is that sufficient economic resources and organisational ability are needed to address the international capital market. Another reason may be that the sources of information for international investors might be limited to corporate websites and annual reports - as opposed to the multitude of news media readily available to investors from the home market. Hence, international investors would be expected to focus on familiarity in disclosure behaviour, where potential investment objects adhere to international standards of reporting such as the IFRS standards for financial reporting and with high levels of voluntary Corporate Governance disclosures, i.e., providing a stamp of quality through transparency.

While transparency can be seen as a positive mechanism in internationally oriented companies, we do not find the level of Corporate Governance disclosure to be relevant in distinguishing between Danish companies on the basis of differences in ownership dispersion. We have shown that company size is a significant mitigating factor in the model testing for ownership dispersion. This is consistent with prior findings that ownership structures of firms are endogeneous (Gorton and Schmid, 1999) and therefore 
provides a relevant contribution to understanding differences in Corporate Governance systems. National institutional settings of the business environment and cultural differences might in effect be mitigation factors as suggested by studies of more countries involving ownership (e.g., Krivogorsky, 2006, Seifert et al., 2005).

Another main finding of our study is that the two prime Corporate Governance mechanisms differ in nature. We find that board independence could be seen as a positive mechanism in Danish companies with dispersed ownership and with an international orientation. In direct contrast to our findings on transparency, we find a larger importance in case of ownership dispersion that in case of international orientation. The signalling of "board independence" may be compared to the chosen "level of transparency" in the sense that both provide information for external purposes. This constitutes a distinct difference between the two-tier system, where internal supervision is defined as part of the board system, and the one-tier system, where board independence is often considered as an internal Corporate Governance measure. Most prior research including board independence has been studies of countries with one-tier board systems (e.g., Gani and Jermias, 2006, Klein et al., 2005, Anderson et al., 2004). That board independence can be an important Corporate Governance mechanism in two-tier board systems is a notable finding and highly relevant for understanding the differences between these systems, see also Krivogorsky (2006).

Our findings have several implications for future research and practice. The positive relationships identified in our study contribute to improved understanding of the 
circumstantial relationship between good Corporate Governance and good corporate performance. This is important in order to interpret differences in prior research findings and provide insight for the design of future studies into the seemingly endogenous nature of many Corporate Governance relationships. The requirement to adhere to the "complyor-explain" rules for Corporate Governance has become commonplace for listed companies. Our study provides insight into valid reasons for differences in compliance. Because companies have different agendas, they may differ in their use of Corporate Governance mechanisms. This insight is an important enabler for fair assessments of company differences of "good" Corporate Governance. Regulators and other capital market participants should acknowledge that companies may differ in their use of Corporate Governance mechanisms for a number of different reasons, including differences in ownership dispersion and international orientation.

\section{NOTES}

\footnotetext{
${ }^{1}$ The data was originally collected to map out the extent to which Danish companies comply with domestic and international corporate governance standards. In an effort to reduce errors and misunderstandings, the sample companies have been asked to read the tables with their own data and to point out incorrect information. A full list of attributes in the data set is available upon request to the authors.

${ }^{2}$ In this study we do not use 44 of the variables in the full dataset. Four of the variables are unrelated background variables such as "total audit fee" and "number of analysts following the company", while 31 are identified as conditioned variables (as an example: if the age of each board member is disclosed, conditioned variables would be "age of youngest board member"; "age of oldest board member" and "average age of board members"). The remaining nine variables, which we do not use, are control variables (untabulated results are available).

${ }^{3}$ The absence of director(s) membership of the board has also been tested as an alternative measure for
} 
board independence. Applying this measure for the independent variable provides similar results as presented using CGBOARDLARSH (not tabulated).

${ }^{4}$ After this process the variance influence factor is below 1.6 for all coefficients in all models, which is a sufficiently low level to ensure no statistical multicollinearity problems in the regression models.

${ }^{5}$ We report all significance levels as two-tailed. Because the predicted directions of the internationalisation proxies are supported, the findings are, however, stronger (i.e., one-tailed significance levels will apply).

${ }^{6}$ We transformed the two continuous variables into categorical variables by letting the value 1 be represented by values larger than 0 , i.e., providing 39 positive observations for ODINSTITUTIONALINV and 26 for ININTLEXPBM. 


\section{REFERENCES}

Adjaoud, F., Zeghal, D. and Andaleeb, S. (2007) The Effect of Board's Quality on Performance: A Study of Canadian Firms. Corporate Governance: An International Review, 15, 623-635.

Anderson, R. C., Mansi, S. A. and Reeb, D. M. (2004) Board Characteristics, Accounting Report Integrity, and the Cost of Debt. Journal of Accounting and Economics, 37, 315-342.

Bebchuk, L., A. and Cohen, A. (2005) The Costs of Entrenched Boards. Journal of Financial Economics, 78, 409-433.

Berger, A. N., Clarke, G. R. G., Cull, R., Klapper, L. and Udell, G. F. (2005) Corporate governance and Bank Performance: A Joint Analysis of the Static, Selection, and Dynamic Effects of Domestic, Foreign, and State Ownership. Journal of Banking \& Finance, 29, 2179-2221.

Botosan, C., A. and Plumlee, M., A. (2002) A Re-examination of Disclosure Level and the Expected Cost of Equity Capital. Journal of Accounting Research, 40, 21-40.

Bradley, N. (2004) Corporate Governance Scoring and the Link Between Corporate Governance and Performance Indicators: in search of the Holy Grail. Corporate Governance: An International Review, 12, 8-11.

Brennan, N. (2006) Boards of Directors and Firm Performance: Is There an Expectations Gap? Corporate Governance: An International Review, 14, 577-594.

Brown, L., D. and Caylor, M., L. (2006) Corporate Governance and Firm Valuation. Journal of Accounting and Public Policy, 25, 409-434.

Brunello, G., Graziano, C. and Parigi, B. (2001) Executive Compensation and Firm Performance in Italy. International Journal of Industrial Organization, 19, 133161.

Chua, C., Tze, Eun, C., S. and Lai, S. (2007) Corporate Valuation Around the World: The Effects of Governance, Growth, and Openness. Journal of Banking \& Finance, 31, 35-35.

Clarke, T. (2004) Cycles of Crisis and Regulation: The Enduring Agency and Stewardship Problems of Corporate Governance. Corporate Governance: An International Review, 12, 153-162.

Core, J., E., Guay, W., R. and Rusticus, T., O. (2006) Does Weak Governance Cause Weak Stock Returns? An Examination of Firm Operating Performance and 
Investors' Expectations. The Journal of Finance, 61, 655-687.

Cremers, K. J. M. and Nair, V., B. (2005) Governance Mechanisms and Equity Prices. The Journal of Finance, 60, 2859-2894.

CSE (2005) Corporate Governance Recommendations. Copenhagen Stock Exchange Committee on Corporate Governance.

Daske, H. (2006) Economic Benefits of Adopting IFRS or US-GAAP - Have the Expected Cost of Equity Capital Really Decreased? Journal of Business Finance \& Accounting, 33, 329-373.

de Andres, P., Azofra, V. and Lopez, F. (2005) Corporate Boards in OECD Countries: Size, Composition, Functioning and Effectiveness. Corporate Governance, 13, 197-210.

Dulewicz, V. and Herbert, P. (2004) Does the Composition and Practice of Boards of Directors Bear Any Relationship to the Performance of their Companies? Corporate Governance: An International Review, 12, 263-281.

Dwivedi, N. and Jain, A. K. (2005) Corporate Governance and Performance of Indian Firms: The Effect of Board Size and Ownership. Employee Responsibilities and Rights Journal, 17, 161-172.

Eng, L. L. and Mak, Y. T. (2003) Corporate Governance and Voluntary Disclosure. Journal of Accounting and Public Policy, 22, 325-345.

Erhardt, N. L., Werbel, J. D. and Shrader, C. B. (2003) Board of Director Diversity and Firm Financial Performance. Corporate Governance: An International Review, $11,102-112$.

Evans, J., Evans, R. and Loh, S. (2002) Corporate Governance and Declining Firm Performance. International Journal of Business Studies, 10, 1-19.

Forker, J. and Green, S. (2000) Corporate Governance and Accounting Models of the Reporting Entity. The British Accounting Review, 32, 375-396.

Fosberg, R. H. and Nelson, M. R. (1999) Leadership Structure and Firm Performance. International Review of Financial Analysis, 8, 83-96.

Gani, L. and Jermias, J. (2006) Investigating the Effect of Board Independence on Performance Across Different Strategies. The International Journal of Accounting, 41, 295-314.

Gelb, D. S. and Zarowin, P. (2002) Corporate Disclosure Policy and the Informativeness of Stock Prices. Review of Accounting Studies, 7, 33-52.

Gietzmann, M. and Ireland, J. (2005) Cost of Capital, Strategic Disclosures and 
Accounting Choice. Journal of Business Finance \& Accounting, 32, 599-634.

Gompers, P., Ishii, J. and Metrick, A. (2003) Corporate Governance and Equity Prices. The Quarterly Journal of Economics, 118, 107-155.

Gorton, G. and Schmid, F. (1999) Corporate Governance, Ownership Dispersion and Efficiency: Empirical Evidence From Austrian Cooperative Banking. Journal of Corporate Finance, 5, 119-140.

Gray, S., J., Meek, G., K. and Roberts, C., B. (1995) International Capital Market Pressures and Voluntary Annual Report Disclosures by U.S. and U.K. Multinationals. Journal of International Financial Management \& Accounting, 6, 43-69.

Haniffa, R. and Hudaib, M. (2006) Corporate Governance Structure and Performance of Malaysian Listed Companies. Journal of Business Finance \& Accounting, 33, 1034-1034.

Healy, P. M. and Palepu, K. G. (2001) Information Asymmetry, Corporate Disclosure, and the Capital Markets: A Review of the Empirical Disclosure Literature. Journal of Accounting \& Economics, 31, 405-440.

Heslin, P. and Donaldson, L. (1999) Precis An Organizational Portfolio Theory of Board Composition. Corporate Governance: An International Review, 7, 81-88.

Ho, C.-K. (2005) Corporate Governance and Corporate Competitiveness: An International Analysis. Corporate Governance: An International Review, 13, 211 253.

Ingley, C. B. and Van der Walt, N. T. (2004) Corporate Governance, Institutional Investors and Conflicts of Interest. Corporate Governance: An International Review, 12, 534-551.

Kang, H., Cheng, M. and Gray Sidney, J. (2007) Corporate Governance and Board Composition: Diversity and Independence of Australian Boards. Corporate Governance, 15, 194-194.

Klein, P., Shapiro, D. and Young, J. (2005) Corporate Governance, Family Ownership and Firm Value: the Canadian evidence. Corporate Governance: An International Review, 13, 769-769.

Krivogorsky, V. (2006) Ownership, Board Structure, and Performance in Continental Europe. International Journal of Accounting, 41, 176-198.

Larcker, D. F., Richardson, S. A. and Tuna, I. (2007) Corporate Governance, Accounting Outcomes, and Organizational Performance. Accounting Review, 82, 963-1009.

Leuz, C. and Verrecchia, R. E. (2000) The Economic Consequences of Increased 
Disclosure. Journal of Accounting Research, 38, 91-124.

Nicholson, G. J. and Kiel, G. C. (2007) Can Directors Impact Performance? A Casebased Test of Three Theories of Corporate Governance. Corporate Governance: An International Review, 15, 585-608.

OECD (2004) Principles of Corporate Governance. OECD, Paris.

Oxelheim, L. and Randøy, T. (2003) The Impact of Foreign Board Membership on Firm Value. Journal of Banking \& Finance, 27, 2369-2392.

Randøy, T. and Nielsen, J. (2002) Company Performance, Corporate Governance, and CEO Compensation in Norway and Sweden. Journal of Management \& Governance, 6, 57-81.

Rhoades, D. L., Rechner, P. L. and Sundaramurthy, C. (2001) A Meta-analysis of Board Leadership Structure and Financial Performance: Are Two Heads Better than One? Corporate Governance: An International Review, 9, 311-320.

Richard, D. and Sofia, P. (2000) International Capital Mobility and Domestic Institutions: Corporate Finance and Governance in Four European Cases. Governance, 13, 119-153.

Rose, C. (2005) The Composition of Semi-Two-Tier Corporate Boards and Firm Performance. Corporate Governance: An International Review, 13, 691-701.

Seifert, B., Gonenc, H. and Wright, J. (2005) The International Evidence on Performance and Equity Ownership by Insiders, Blockholders, and Institutions. Journal of Multinational Financial Management, 15, 171-192.

Williams, M. (2004) Discussion of "The Role of Information Precision in Determining Cost of Equity Capital". Review of Accounting Studies, 9, 261-264.

Yermack, D. (1996) Higher Market Valuation of Companies with a Small Board of Directors. Journal of Financial Economics, 40, 185-211. 
Figure 1: Relationships Examined in this Study

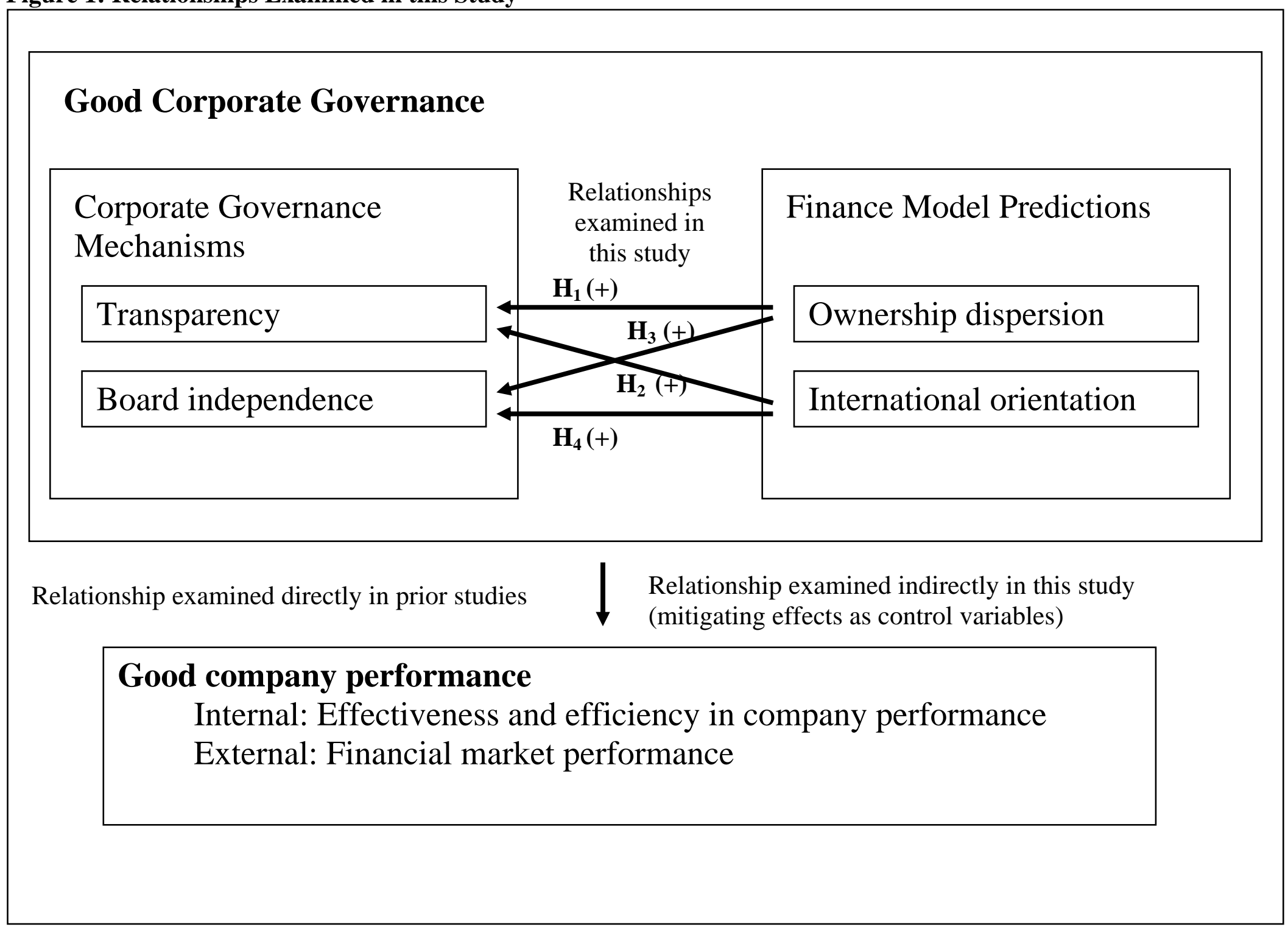


Table 1: Overview of Variables in the Dataset

\begin{tabular}{|c|c|c|}
\hline Corporate Governance variables & 127 & Total number of CG variables \\
\hline $\begin{array}{l}\text { Control variables for } \\
\text { performance, risk and size }\end{array}$ & 13 & $\begin{array}{l}\text { The PF variables include: Total capital; Book } \\
\text { value of total assets; Solvency; ROIC; } \\
\text { EBITDA-margin; ROA; ROE; Market value } \\
\text { (ultimo); Volatility; Tobin's Q; Beta; Book } \\
\text { value (ultimo); Price to book ratio. }\end{array}$ \\
\hline Dataset 2004 & 140 & Total number of variables in dataset \\
\hline Dependent variables & $\begin{array}{r}82 \\
2 \\
84\end{array}$ & $\begin{array}{l}\text { Combined to disclosure measure } \\
\text { Combined to board independence measure } \\
\text { Total used }\end{array}$ \\
\hline Independent variables & $\begin{array}{r}4 \\
4 \\
4 \\
12 \\
\end{array}$ & $\begin{array}{l}\text { Ownership dispersion } \\
\text { Internationalisation } \\
\text { Control and performance } \\
\text { Total used }\end{array}$ \\
\hline Unused variables & $\begin{array}{r}9 \\
4 \\
31 \\
44 \\
\end{array}$ & $\begin{array}{l}\text { Control variables } \\
\text { Background variables } \\
\text { Conditioned variables } \\
\text { Total unused variables }\end{array}$ \\
\hline
\end{tabular}


Table 2: Descriptive Statistics

\begin{tabular}{|c|c|c|c|c|c|c|c|}
\hline Continuous variables & & $\begin{array}{l}\text { Pred. } \\
\text { Sign }\end{array}$ & Mean & $\begin{array}{l}\text { Standard } \\
\text { deviation }\end{array}$ & Minimum & Median & Maximum \\
\hline \multirow{2}{*}{ Corporate Governance (CG) } & CGDISCLEVEL & & 0.5245 & 0.1376 & 0.2805 & 0.5122 & 0.9146 \\
\hline & CGBOARDLARSH & & 0.8367 & 0.2067 & 0.0000 & 0.8900 & 1.0000 \\
\hline Ownership dispersion (OD) & ODINSTITUTIONALINV & + & 0.0557 & 0.0851 & 0.0000 & 0.0000 & 0.3700 \\
\hline Internationalization (IN) & INFOREI GNSH & + & 0.0729 & 0.1583 & 0.0000 & 0.0000 & 0.8500 \\
\hline \multirow{4}{*}{ Performance, risk and size (PF) } & PFEBITDA & $?$ & -0.701 & 8.809 & -87.720 & 0.158 & 2.446 \\
\hline & PFPTB & $?$ & 3.267 & 8.799 & -0.534 & 1.670 & 83.810 \\
\hline & PFBETA & $?$ & 0.527 & 0.377 & -0.070 & 0.430 & 1.760 \\
\hline & PFTOTALCAPITAL & $?$ & 14.201 & 1.769 & 9.384 & 14.002 & 19.687 \\
\hline Categorical variables & & & \multicolumn{3}{|c|}{ Proportion: } & 0 & 1 \\
\hline \multirow{3}{*}{ Ownership dispersion (OD) } & ODLARGESH & + & \multicolumn{3}{|c|}{$\begin{array}{l}\text { 0: large shareholders; } \\
\text { 1: no large shareholders }\end{array}$} & 29 & 71 \\
\hline & ODSHARECLASSES & + & \multicolumn{3}{|c|}{$\begin{array}{l}\text { 0: more shareclasses; } \\
\text { 1: one shareclass }\end{array}$} & 74 & 26 \\
\hline & ODRESTRICTIONS & + & \multicolumn{3}{|c|}{ 0: no restrictions; 1 : restrictions } & 76 & 24 \\
\hline \multirow{3}{*}{ Internationalization (IN) } & INIFRSFIRST & + & \multicolumn{3}{|c|}{$0:$ no; $1:$ yes } & 85 & 15 \\
\hline & INFOREIGNBM & + & \multicolumn{3}{|c|}{ 0: no; 1 : yes } & 68 & 32 \\
\hline & ININTLEXPBM & + & \multicolumn{3}{|c|}{$0:$ no; $1:$ yes } & 37 & 63 \\
\hline
\end{tabular}

The continuous dependent variables: CGDISCLEVEL is the overall disclosure level. CGBOARDLARSH is the proportion of the board not representing large shareholders, i.e. an independence proxy.

The continuous independent variables: ODINSTITUTIONALINV is the part of shares owned by institutional investors.

INFOREIGNSH is the part of equity held by foreign shareholders. PFEBITDA is the earnings before income, taxes, depreciation and amortization margin, PFPTB the price to book ratio, PFBETA the beta value, and PFTOTALCAPITAL is the natural logarithm to the total capital.

The categorical independent variables (binary variables): ODLARGESH is set if shareholder(s) do not have more than $20 \%$ of votes, ODSHARECLASSES is set if company does not have more than one share-class, ODRESTRICTIONS is set if ownershiprestrictions on capital and/or votes, I NIFRSFIRST is set if company is IFRS first adapter, INFOREIGNBM is set if company has foreign board member(s), I NI NTLEXPBM is set if company has board member(s) with international experience. 
Table 3: Pearson Correlation Matrix

\begin{tabular}{|c|c|c|c|c|c|c|c|c|c|c|c|c|c|c|}
\hline & 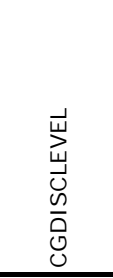 & 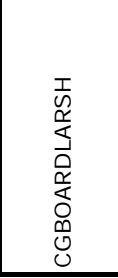 & 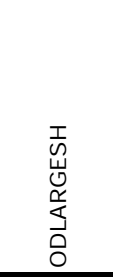 & 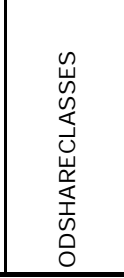 & 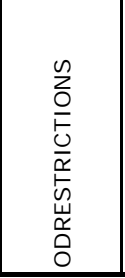 & 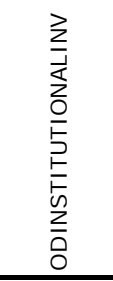 & 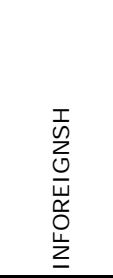 & 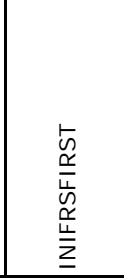 & 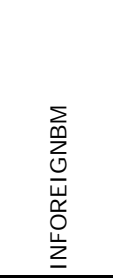 & 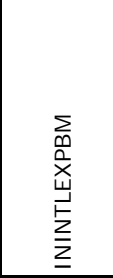 & 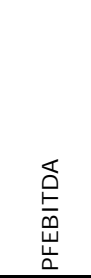 & $\frac{\infty}{\frac{0}{a}}$ & 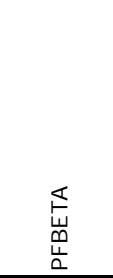 & 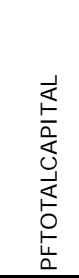 \\
\hline CGDISCLEVEL & 1.000 & & & & & & & & & & & & & \\
\hline CGBOARDLARSH & 0.022 & 1.000 & & & & & & & & & & & & \\
\hline ODLARGESH & -0.103 & $0.422^{* * *}$ & 1.000 & & & & & & & & & & & \\
\hline ODSHARECLASSES & $-0.194^{*}$ & 0.057 & $0.329^{* * *}$ & 1.000 & & & & & & & & & & \\
\hline ODRESTRICTIONS & -0.057 & $0.221^{* *}$ & $0.260^{* * *}$ & $0.201^{* *}$ & 1.000 & & & & & & & & & \\
\hline ODINSTITUTIONALINV & 0.048 & 0.092 & -0.118 & $-0.369^{* * *}$ & -0.096 & 1.000 & & & & & & & & \\
\hline INFOREIGNSH & $0.403^{* * *}$ & 0.003 & $0.200^{* *}$ & 0.033 & -0.061 & -0.042 & 1.000 & & & & & & & \\
\hline INIFRSFIRST & $0.346^{* * *}$ & 0.074 & 0.040 & -0.070 & 0.026 & 0.048 & $0.195^{*}$ & 1.000 & & & & & & \\
\hline INFOREI GNBM & $0.385^{* * *}$ & -0.083 & -0.013 & 0.016 & -0.135 & $-0.180^{*}$ & 0.164 & $0.312^{* * *}$ & 1.000 & & & & & \\
\hline ININTLEXPBM & $0.445^{* * *}$ & 0.083 & -0.058 & -0.076 & $-0.200^{* *}$ & -0.007 & $0.314^{* * *}$ & $0.206^{* *}$ & $0.481^{* * *}$ & 1.000 & & & & \\
\hline PFEBITDA & -0.092 & 0.159 & 0.061 & -0.057 & 0.062 & 0.061 & 0.050 & $-0.260^{* * *}$ & -0.150 & -0.082 & 1.000 & & & \\
\hline PFPTB & -0.032 & $-0.269^{* * *}$ & -0.041 & 0.099 & -0.041 & -0.088 & -0.028 & 0.035 & -0.046 & -0.073 & 0.008 & 1.000 & & \\
\hline PFBETA & 0.160 & $0.218^{* *}$ & 0.100 & 0.051 & $-0.339^{* * *}$ & -0.113 & $0.272^{* * *}$ & 0.084 & $0.310^{* * *}$ & $0.441^{* * *}$ & 0.023 & -0.056 & 1.000 & \\
\hline PFTOTALCAPITAL & $0.422^{* * *}$ & $0.203^{* *}$ & 0.085 & -0.067 & 0.069 & -0.048 & $0.443^{* * *}$ & 0.025 & 0.162 & $0.256^{* *}$ & 0.029 & $-0.195^{*}$ & $0.351^{* * *}$ & 1.000 \\
\hline
\end{tabular}

$* * *$. Correlation is significant at the 0.01 level (2-tailed).

**. Correlation is significant at the 0.05 level ( 2 -tailed).

*. Correlation is significant at the 0.10 level (2-tailed). 
Table 4: The Effect of Ownership Dispersion and I nternational Orientation on Corporate Governance Transparency.

\begin{tabular}{|c|c|c|c|c|c|}
\hline \multirow[t]{2}{*}{ Dep.: CGDISCLEVEL } & \multirow{2}{*}{$\begin{array}{l}\text { Predict. } \\
\text { sign }\end{array}$} & \multicolumn{2}{|c|}{$\frac{\text { H1 (Ownership }}{\text { dispersion): }}$} & \multicolumn{2}{|c|}{$\frac{\text { H2 (International }}{\text { orientation): }}$} \\
\hline & & Coefficient & t-stat. & Coefficient & t-stat. \\
\hline I NTERCEPT & $?$ & 0.092 & $(0.81)$ & 0.114 & $(1.14)$ \\
\hline ODLARGESH & + & -0.012 & $(-0.37)$ & & \\
\hline ODSHARECLASSES & + & -0.058 & $(-1.65)$ & & \\
\hline ODRESTRICTIONS & + & -0.035 & $(-0.96)$ & & \\
\hline ODINSTITUTIONALINV & + & -0.007 & $(-0.04)$ & & \\
\hline I NFOREI GNSH & + & & & $0.136^{*}$ & (1.68) \\
\hline I NI FRSFI RST & + & & & $0.081^{* *}$ & $(2.42)$ \\
\hline I NFOREI GNBM & + & & & $0.049^{*}$ & (1.78) \\
\hline I NI NTLEXPBM & + & & & $0.078^{* * *}$ & $(2.76)$ \\
\hline PFEBITDA & $?$ & -0.002 & $(-1.15)$ & -0.000 & $(-0.03)$ \\
\hline PFPTB & $?$ & 0.001 & $(0.70)$ & 0.001 & $(0.56)$ \\
\hline PFBETA & $?$ & -0.005 & $(-0.12)$ & $-0.067^{* *}$ & $(-1.99)$ \\
\hline PFTOTALCAPITAL & $?$ & $0.034^{* * *}$ & $(4.33)$ & $0.025^{* * *}$ & $(3.44)$ \\
\hline Observations & & 10 & & 10 & \\
\hline Adj. $R^{2}$ & & 0.7 & & 0. & \\
\hline F-Ratio & & 3.5 & & 8.5 & \\
\hline
\end{tabular}

P-values: *** Significant at .01;** Significant at .05; * Significant at .10

Ordinary least squares coefficients and t-statistics are shown. The dependent variable is CGDISCLEVEL, the overall disclosure level. ODLARGESH is set if shareholder(s) do not have more than $20 \%$ of votes,

ODSHARECLASSES is set if company does not have more than one share-class, ODRESTRICTIONS is set if ownership-restrictions on capital and/or votes, and ODINSTITUTIONALINV is the part of shares owned by institutional investors. INFOREIGNSH is the part of equity held by foreign shareholders, INIFRSFIRST is set if company is IFRS first adopter, I NFOREIGNBM is set if company has foreign board member(s), and I NI NTLEXPBM is set if company has board member(s) with international experience. PFEBITDA is the earnings before income, taxes, depreciation and amortization margin, PFPTB the price to book ratio, PFBETA the beta value, and PFTOTALCAPITAL is the natural logarithm to the total capital. 
Table 5: The Effect of Ownership Dispersion and I nternational Orientation on Board I ndependence.

\begin{tabular}{|c|c|c|c|c|c|}
\hline \multirow[t]{2}{*}{ Dep.: CGBOARDLARSH } & \multirow{2}{*}{$\begin{array}{c}\text { Predict. } \\
\text { sign }\end{array}$} & \multicolumn{2}{|c|}{$\frac{\text { H3 (Ownership }}{\text { dispersion): }}$} & \multicolumn{2}{|c|}{$\frac{\text { H4 (International }}{\text { orientation): }}$} \\
\hline & & Coefficient & t-stat. & Coefficient & t-stat. \\
\hline I NTERCEPT & $?$ & $0.587^{* * *}$ & $(3.71)$ & $0.538^{* * *}$ & $(3.04)$ \\
\hline ODLARGESH & + & $0.138^{* * *}$ & (3.05) & & \\
\hline ODSHARECLASSES & + & 0.045 & $(0.92)$ & & \\
\hline ODRESTRICTIONS & + & $0.120^{* *}$ & $(2.36)$ & & \\
\hline ODINSTITUTIONALINV & + & $0.468^{* *}$ & $(2.02)$ & & \\
\hline I NFOREI GNSH & + & & & -0.215 & $(-1.51)$ \\
\hline I NI FRSFI RST & + & & & $0.113^{*}$ & $(1.91)$ \\
\hline I NFOREI GNBM & + & & & $-0.099^{* *}$ & $(-2.01)$ \\
\hline I NI NTLEXPBM & + & & & 0.027 & $(0.54)$ \\
\hline PFEBITDA & $?$ & 0.003 & (1.33) & $0.004^{*}$ & $(1.86)$ \\
\hline PFPTB & $?$ & $-0.005^{* *}$ & $(-2.50)$ & $-0.006^{* *}$ & $(-2.55)$ \\
\hline PFBETA & $?$ & $0.143^{* *}$ & $(2.55)$ & $0.116^{*}$ & $(1.95)$ \\
\hline PFTOTALCAPITAL & $?$ & 0.005 & $(0.41)$ & 0.019 & $(1.49)$ \\
\hline Observations & & 10 & & 10 & \\
\hline $\operatorname{Adj} . R^{2}$ & & 0 & & 0.7 & \\
\hline F-Ratio & & 6.0 & & 3.05 & \\
\hline
\end{tabular}

P-values: *** Significant at .01;** Significant at .05; * Significant at .10

Ordinary least squares coefficients and t-statistics are shown. The dependent variable is CGBOARDLARSH, the proportion of the board not representing large shareholders. ODLARGESH is set if shareholder(s) do not have more than $20 \%$ of votes, ODSHARECLASSES is set if company does not have more than one share-class, ODRESTRICTIONS is set if ownership-restrictions on capital and/or votes, and ODINSTITUTIONALINV is the part of shares owned by institutional investors. INFOREIGNSH is the part of equity held by foreign shareholders, I NIFRSFIRST is set if company is IFRS first adopter, INFOREI GNBM is set if company has foreign board member(s), and I NINTLEXPBM is set if company has board member(s) with international experience. PFEBITDA is the earnings before income, taxes, depreciation and amortization margin, PFPTB the price to book ratio, PFBETA the beta value, and PFTOTALCAPITAL is the natural logarithm to the total capital. 
Table 6: The Total Effect of Ownership Dispersion and I nternational Orientation on Corporate Governance Transparency and Board I ndependence.

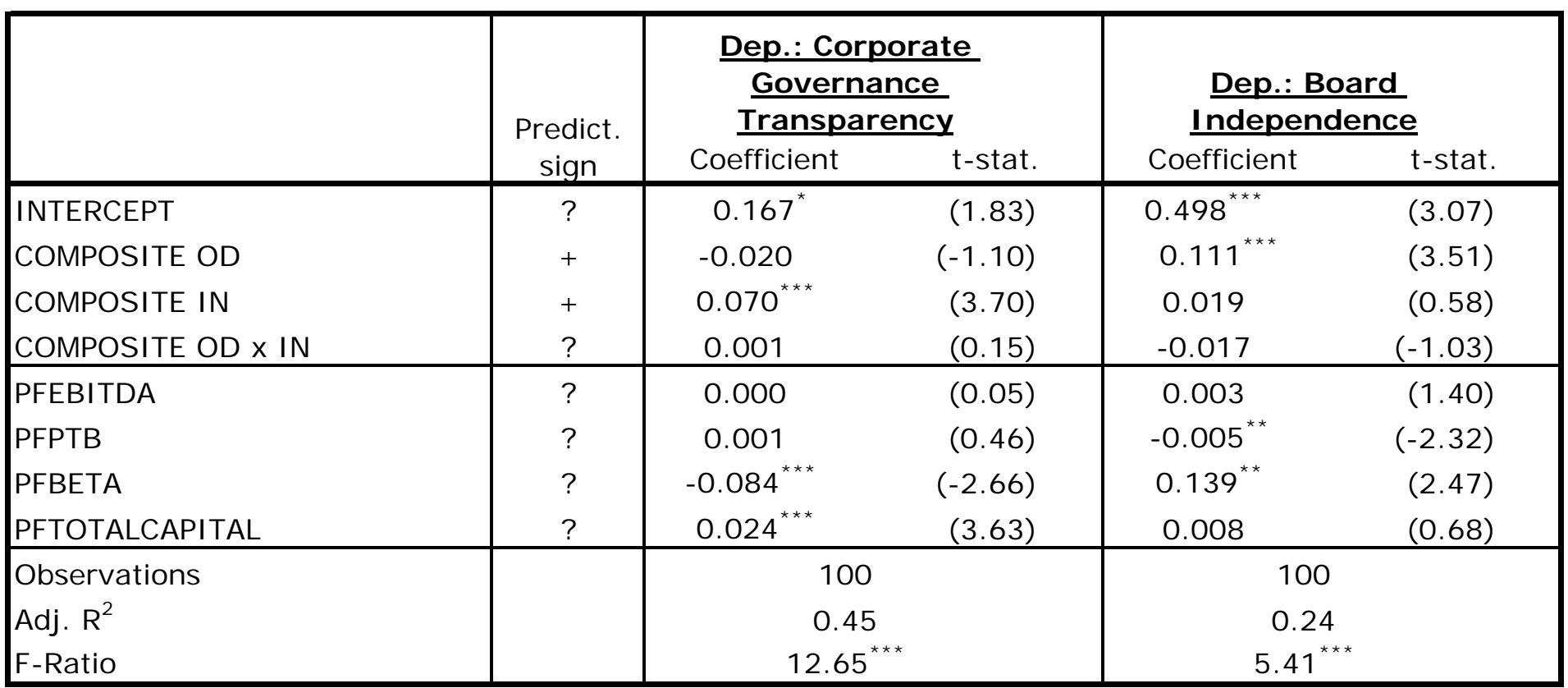

P-values: $* * *$ Significant at $.01 ; * *$ Significant at .05; * Significant at .10

Ordinary least squares coefficients and t-statistics are shown. The dependent variables are CGDISCLEVEL, the overall disclosure level; and CGBOARDLARSH, the proportion of the board not representing large shareholders. COMPOSITE OD is the simple sum of our 4 ownership dispersion variables, i.e. ODLARGESH, ODSHARECLASSES, ODRESTRICTIONS, and ODINSTITUTIONALINV. The latter is converted to a categorical variable where 1 represents larger than 0. COMPOSITE IN is the simple sum of our 4 international orientation variables, i.e. I NFOREI GNSH, I NIFRSFIRST, I NFOREIGNBM, and INI NTLEXPBM. The first is converted to a categorical variable where 1 represents larger than 0. COMPOSITE OD $x$ IN is COMPOSITE OD multiplied by COMPOSITE IN, i.e. the interaction between the two. PFEBITDA is the earnings before income, taxes, depreciation and amortization margin, PFPTB the price to book ratio, PFBETA the beta value, and PFTOTALCAPITAL is the natural logarithm to the total capital. 


\section{Working Papers from Accounting Research Group}

A-2008-02 Claus Holm \& Finn Schøler: Reduction of Asymmetric Information through Corporate Governance Mechanisms - The Importance of Ownership Dispersion and International Orientation.

A-2008-01 Gudrun Baldvinsdottir, John Burns, Hanne Nørreklit \& Robert W. Scapens: The Image of Accountants: From Bean Counters to Extreme Accountants.

A-2007-05 Claus Holm, Lars Bo Langsted \& Jesper Seehausen: An Examination of Actual Fraud Cases With a Focus on the Auditor's Responsibility.

A-2007-04 Hanne Nørreklit: MANAGEMENT ART - The Royal Danish Opera's Artistic Director Kasper Bech Holten as case.

A-2007-03 Hanne Nørreklit, Lennart Nørreklit \& Falconer Mitchell: The paradigmatic foundations of accounting practice

A-2007-02 Christian Nielsen, Edward Vali, Rene Hvidberg, Jesper Timmermann Jensen \& Thomas Pihlkjær Madsen: Business Models, transparency and efficient stock price formation: Conclusions and practical advice from a research project into Investor Relations best practice.

A-2007-01 Christian Nielsen \& Mona Toft Madsen: Discourses of transparency in the Intellectual Capital reporting debate: Moving from generic reporting models to management defined information.

A-2006-02 Pall Rikhardsson, Peter Best \& Claus Juhl-Christensen: Sarbanes-Oxley compliance, internal control and ERP systems: Automation and the case of mySAP ERP.

A-2006-01 Claus Holm \& Niels Steenholdt: Explaining Differences in Learning Outcomes in Auditing Education - The Importance of Background Factors, Prior Knowledge and Intellectual Skills.

\section{Before November 2006}

FINANCIAL REPORTING

R-2006-04 Finn Schøler: Is there something rotten in Denmark? A true story about earnings management to avoid small losses.

R-2006-03 Finn Schøler: The accrual anomaly - focus on changes in specific unexpected accruals results in new evidence.

R-2006-02 Claus Holm \& Pall Rikhardsson: Experienced and Novice Investors: Does Environmental Information Influence on Investment Allocation Decisions? 
R-2006-01 Peder Fredslund Møller: Settlement-date Accounting for Equity Share Options - Conceptual Validity and Numerical Effects.

R-2005-04 Morten Balling, Claus Holm \& Thomas Poulsen: Corporate governance ratings as a means to reduce asymmetric information.

R-2005-03 Finn Schøler: Earnings management to avoid earnings decreases and losses.

R-2005-02 Frank Thinggaard \& Lars Kiertzner: The effects of two auditors and nonaudit services on audit fees: evidence from a small capital market.

R-2005-01 Lars Kiertzner: Tendenser i en ny international revisionsstandardisering - relevante forskningsspørgsmål i en dansk kontekst.

R-2004-02 Claus Holm \& Bent Warming-Rasmussen: Outline of the transition from national to international audit regulation in Denmark.

R-2004-01 Finn Schøler: The quality of accruals and earnings - and the market pricing of earnings quality.

\section{MANAGEMENT ACCOUNTING}

M-2006-05 Pall Rikhardsson, Peter Best, Peter Green \& Michael Rosemann: Business Process Risk Management, Compliance and Internal Control: A Research Agenda.

M-2006-04 Steen Nielsen \& Erland Hejn Nielsen: System Dynamic Modelling for a Balanced Scorecard: With a Special Emphasis on Skills, Customer Base, and WIP.

M-2006-03 Iens Christian Pontoppidan: Økonomistyring af værdi - set i et værdibaseret ledelsesperspektiv.

M-2006-02 Iens Christian Pontoppidan: Risiko og værdibaseret ledelse - set i et økonomistyringsperspektiv.

M-2006-01 Morten Jakobsen: A survey of trust, control and information in networks.

M-2005-07 Pall Rikhardsson \& Pernille Kræmmergaard: Identifying the effects of Enterprise System implementation and use: Examples from Denmark.

M-2005-06 Pall Rikhardsson: Accounting for Health and Safety costs: Review and comparison of selected methods.

M-2005-05 Pall Rikhardsson, Carsten Rohde \& Anders Rom: Exploring Enterprise Systems and Management Control in the Information Society: Developing a Conceptual Framework. 
M-2005-04 Jesper Thyssen, Poul Israelsen \& Brian Jørgensen: Activity Based Costing as a method for assessing the economics of modularization - a case study and beyond.

M-2005-03 Christian Nielsen: Modelling transparency: A research note on accepting a new paradigm in business reporting.

M-2005-02 Pall Rikhardsson \& Claus Holm: Do as you say - Say as you do: Measuring the actual use of environmental information in investment decisions.

M-2005-01 Christian Nielsen: Rapporteringskløften: En empirisk undersøgelse af forskellen imellem virksomheders og kapitalmarkedets prioritering af supplerende informationer.

M-2004-03 Christian Nielsen: Through the eyes of analysts: a content analysis of analyst report narratives.

M-2004-02 Christian Nielsen: The supply of new reporting - plethora or pertinent.

M-2004-01 Christian Nielsen: Business reporting: how transparency becomes a justification mechanism. 
ISBN 9788778823120

Department of Business Studies

Aarhus School of Business

University of Aarhus

Fuglesangs Allé 4

DK-8210 Aarhus V - Denmark

Tel. +4589486688

Fax +4586150188

www.asb.dk 